\title{
A Visit to the Yalu Region and Central Manchuria
}

\section{Author(s): Robert T. Turley}

Source: The Geographical Journal, Vol. 23, No. 4 (Apr., 1904), pp. 473-481

Published by: geographicalj

Stable URL: http://www.jstor.org/stable/1775501

Accessed: 27-06-2016 03:49 UTC

\section{Your use of the JSTOR archive indicates your acceptance of the Terms \& Conditions of Use, available at}

http://about.jstor.org/terms

JSTOR is a not-for-profit service that helps scholars, researchers, and students discover, use, and build upon a wide range of content in a trusted digital archive. We use information technology and tools to increase productivity and facilitate new forms of scholarship. For more information about JSTOR, please contact support@jstor.org.

The Royal Geographical Society (with the Institute of British Geographers), Wiley are collaborating with JSTOR to digitize, preserve and extend access to The Geographical Journal 
Loch an Tuirc.-Entomostraca were numerous, but of few species. Rotifera were scarce. Filamentous Algæ were abundant, but there were few Desmids.

Loch Beannach.-Organisms were not very abundant. Only the commonest pelagic Extomostraca were present. Rotifera were more numerous, including, in addition to the usual pelagic srecies, Gastropus stylifer and a species of Ploesoma.

Loch na Doire Daraich.-The very abundant fauna of this loch closely resembled that of the adjacent Loch Druim Suardalain, the most notable difference being the more numerous Rotifera. Among these were Floscularia pelagica, Triarthra longiseta, Pterodina patina, Copeus cerberus, and Dinocharis Collinsii. Among the numerous Desmids were Micrasterias furcata, M. pinnatafida, Staurastrum grande, and S. longispinum.

Loch Druim Suardalain.-This shallow loch had the richest fauna found in the lochs of the district. The flora was also very rich. About a dozen spzcies of Rotifera were seen, including Callidina Brycei. Orer thirty species of Desmids occurred, among which were Staurastrum grande, S. ophiura, and S. sexangulare. 'There was nothing among the Entomostraca calling for remark, only the commoner pelagic and shallow-water species being observed.

Loch Maol a' Choire.-Crustacea were very abundant, including a species of Gammarus. Diaptomus Wierzejskii was the only Calanid observed. It was in a collection from this loch that the species was discovered in Britain by Dr. Scott. The usual pelagic Rotifera were present. No Desmids were seen.

Loch Awe.-The most abundant organism was a variety of Diaptomus Wierzejskii. Sid $a$ was seen here, and in no other lake in the district, being somewhat late in the season for this species. Very few Rotifera or Algæ were noticed.

\section{SOUTHERN MANCHURIA AND KOREA.*}

\section{A VISIT TO THE YALU REGION AND CENTRAL MANCHURIA.}

By ROBERT T. TURLEY.

IT is proposed this evening to briefly describe the Yalu district, especially on the Manchurian side. It may be explained that I have, as agent of the British and Foreign Bible Society, had many opportunities of wandering over this region during the past seventeen years.

Let us first visit Chifu, and see the wonderful vineyards and fruit gardens, and thus comprehend how the now almost barren hills around Port Arthur, and especially Dalny, could be easily made productive and valuable, as the soil, rocks, and climate are similar. The vines are Italian, and grow well on these hillsides, if grafted on stocks of the

* Abstract of lectures at the Royal Geographical Society, March 7, 1904. Map, p. 518. 
Siberian wild vine. The fruit trees are American, grafted on native stocks.

A 60-mile steam across to the Liaotung promontory leads us to the Lao Tie Shan, or "Venerable Iron mountain," a mass of basaltic rock, which forms the extreme point. Climbing over this mountain, we shall probably see numbers of the large spotted eagle, which, tired of Mongolian lamb, have come down to meet the geese. Some of his kind also remain near Shan Hai Kuan, but this mountain is a favourite point of vantage for the wildfowl, where the eagles await and whence they follow the enormous flocks which converge on Mukden, where there pass

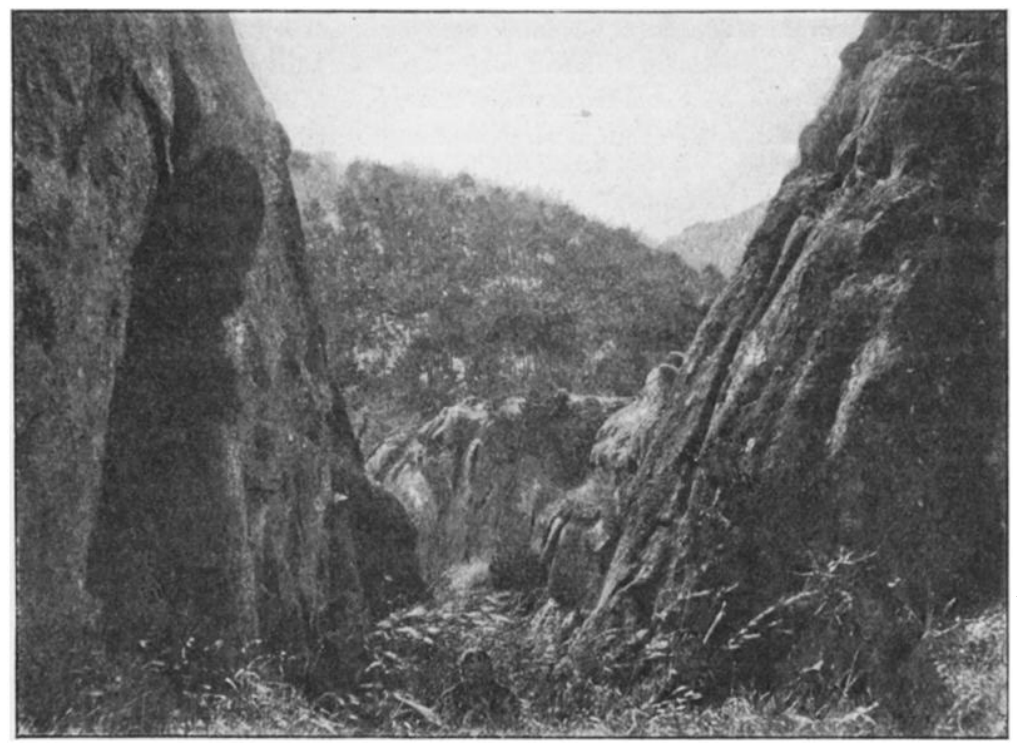

MOUNTAIN SCENERY NEAR KU PANG TZU, WEST OF 'THE LIU PLAIN.

more birds of passage than can be imagined. The Lao Tie Shan was long an eagle preserve, where birds were netted and sent to Peking as part of the Manchurian tribute; the wing feathers being used for the Manchu arrows of the palace archers, the tail feathers for the Imperial fans, which are so much valued.

Wandering eastwards, we come to a large inland shallow piece of water which, with dredging, will form the grand west harbour of Port Arthur. Facing down on this, and nearly opposite the one and only entrance to both harbours, is the recently laid out and partly built new town, which bids fair to become the most imposing city in the Far East. Around a low hill, directly facing the harbour-mouth, we suddenly come upon a fine view of the large basin, the docks, arsenal, military town, Chinese new town on the hill-side in the distance, and the railway 
terminus, with its heaps of stores, at our feet. The train, up a sharp incline, quickly brings us to thriving native villages, growing rich with such a good market near by. The country is more open, with hills on either side towards the sea. Presently the line winds along the north shore. In summer waves lap against the embankment, but at this season, as far out as the eye can see is a wild wilderness of ice-in strong contrast with the open water a few miles away on the opposite shore. The ice protects the railway in winter from enemies at sea, and in summer an embankment could easily be raised to safeguard the trains. There are some good engineering work and cuttings. Passing

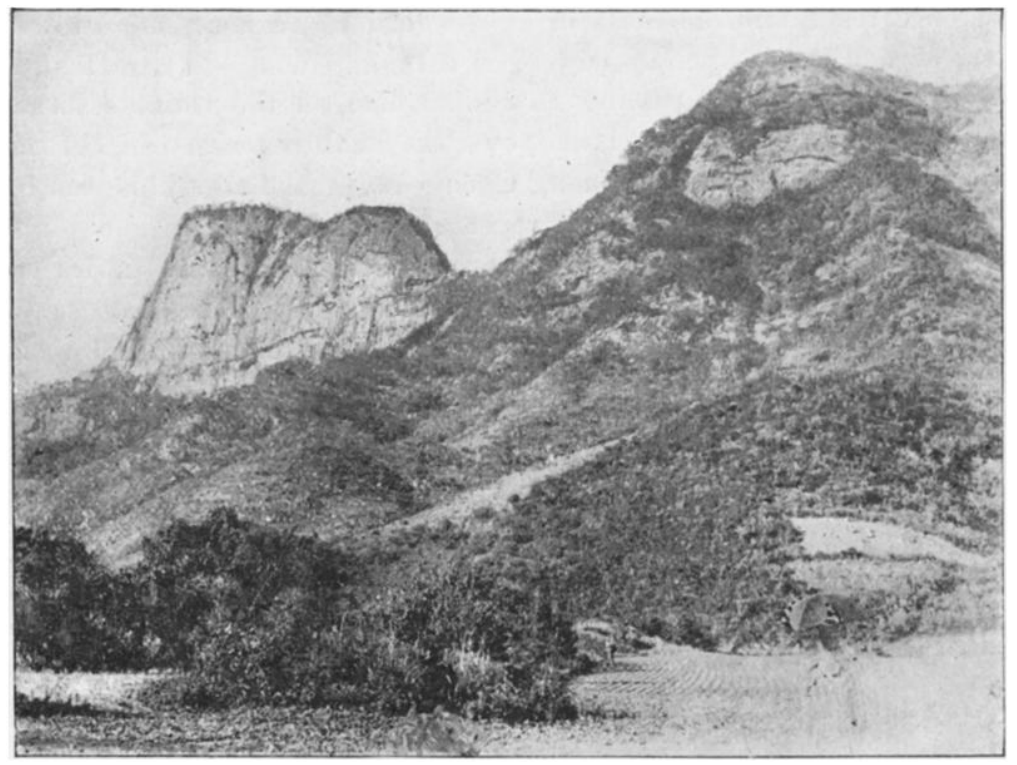

MOUNTAIN SCENERY NEAR THE YALU.

over a limestone undulating country, we come down to Dalny, where much money has been spent, and which would, all being well, become a truly beautiful place. Dry bracing cold in winter and usually pleasant summers, with clean, clear water for bathing, pure drinking-water, and pretty hills, it should be an ideal health resort. Across in a nook on the northern shore of Ta-lien Wan bay. is the military post of Ta-lien Wan, with its own branch railway. Leaving Daln5, we soon bisect the narrow neck connecting the promontory with the mainland. The sea, on either side, is very shallow for miles out. Leaving the train at Chin-Chu Ting station, we take a Chinese mule-cart, and jog eastwards over stony paths to the little port and town of $\mathrm{Pi}$ Tze Woa, strongly held by a Russian force. The harbour is, unlike Port Arthur and Dalny, blocked with ice until nearly the end of March. On the hill 
commanding the harbour is an old Korean citadel. The Japanese landed here in 1894. The road along near the coast-line is fairly good in all weathers. The rivers, above the tidal limits, are easily fordable, except in the summer rainy season. The population grows less and less each year, as the bare and denuded hills send down their quota of sand and stones to destroy the fields. There is, however, much well-cultivated corn land, and, inland, wild silk is"a principal source of wealth.

Past the town and small sea-river port of Ta Chuang Ho, and a few smaller places, we come on to the low blue marl and peat plain. The marl is much used as a fertilizer on the fields. The peat is hard, and cuts out into solid bricks and is the chief fuel of the district, over which is a once respectable military or raised road to Ta $\mathrm{Ku}$ Shan, a town of some eight thousand people with good caravan tracks-(1) to Hsiu Yen and Newchwang port, passing Ta Shih Chiao on the Chinese Eastern Railway; (2) To An Tung Hsien, over the small but rich plain of Lung Wang Miao; (3) To Fêng Huang Chêng and Mukden. This was once a flourishing seaport, but from repeated raids of robbers and pirates, together with the shifting of the river Ta Yang Hö several miles eastwards, and the silting up of the old harbour, trade has gone down. There is, however, usually much grain stored here in winter for shipment by junks in summer. The sea at low water is far out. The river-mouth is much silted up, and only the smaller sea-junks can enter, excepting at spring tides.

Eastward, over a road with many tidal creeks, we come to Ta Tung $\mathrm{Ku}$, passing another small port en route. Ta Tung $\mathrm{Ku}$ is a wretchedly dirty low-lying town, with more sickness, owing to bad water, than can be described. Down the creek on which this town lies, past the huge timber yards, we come out into the noble Yalu, with its water rising and falling 30 feet at spring tides, as it does more or less at Chemulpho. The sandbanks at low water stretch for miles, and ships can sit on these, whilst their crew play cricket, etc. The mouth of the river is full of floating hummocks of ice, and cannot be entered by ships from November 30 to the middle of March. On the far side is the little Korean village of Yong-am-po, where the Russian Lumber Syndicate has its headquarters. Up-river, about 20 miles or more from Ta Tung $\mathrm{Ku}$ creek, on the Chinese side, is a small headland with, in the open season, deep water close to shore; on this rising ground the American consul suggested that the new port should be placed, because An Tung Hsien, 10 miles further up, is also low lying and has bad drinkingwater. It is also subject to inundations.

An Tung Hsien, or Sba Ho Tze, is a thriving town of, probably, 20,000 people, doing a large import and export trade with s9a-going junks. There is a respectable Bund and landing-place with custom house, organized by an intelligent native commissioner some years since. A few miles up-river bring us to Chiu Lien Cheng, or "nine 
consecutive citadels," once upon a time of some importance, now a small village with the remains of old earthworks. Here the Imperial road and telegraph line from Mukden to Seoul crosses the Yalu, and here the Cbinese collected immense stores of war material, duly handing over the same to the Japanese invaders. The opposite shore, and some distance inland and down to the sea, is some of the richest corn and rice land in Korea. Up-river a short distance, on a hilly promontory, is the miserable and dilapidated old Korean city of $\mathrm{Yi}$-chu, or Wi-chu, once a famous political and trading centre. The Yalu narrows above Yi-chu and is confined by hills, but it is navigable for good large junks up to the

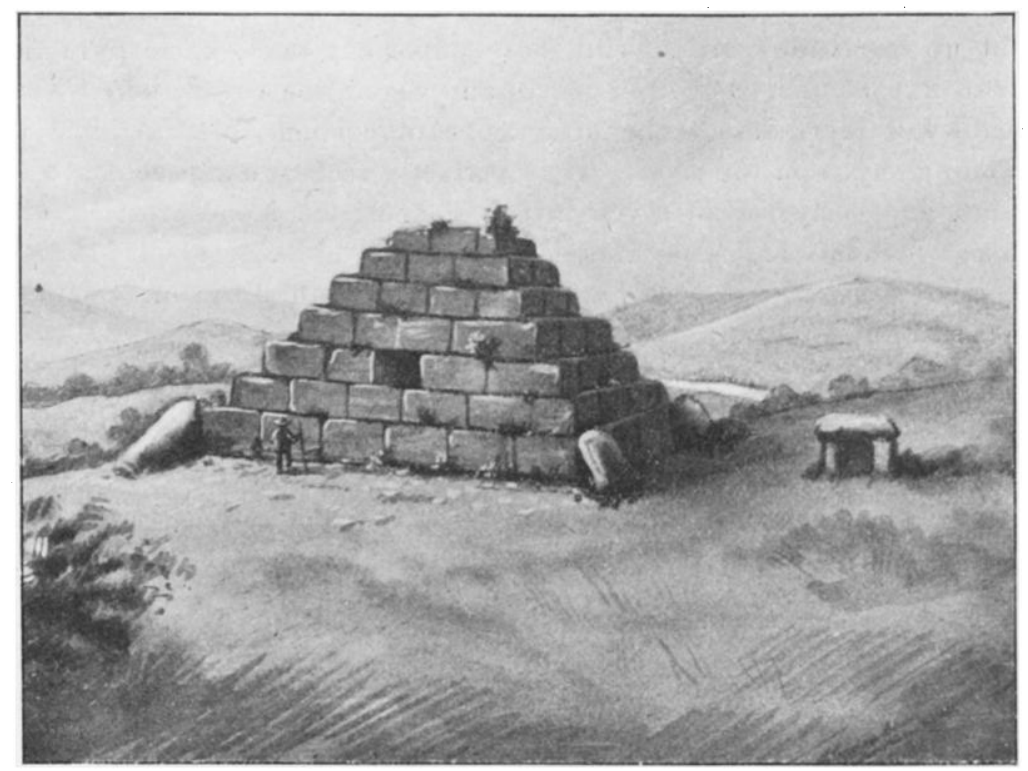

ONE OF SEVERAL ANCIENT TOMBS NeAR TUNG KU, ON THE UPPER YALU.

mouth of the Hün Chiang. Sailing up-river is somewhat slow work, however, as the current is usually strong. Small steamers to tow junks and barges up-stream are needed. On the Korean side the hills are more or less parallel with the river, with valleys, enfolding villages, breaking here and there. For over 100 miles up-river, excepting small fir trees, the Korean hills have but little wood on them. On the Chinese side, numberless short valleys come down, roughly at right angles, from a main ridge inland, fairly wide and cultivated, but with usually narrow entrances from the Yalu. These hills, once forest, are now covered with scrub oak, on which much silk might be raised.

We may continue by our mule-cart or sledge, if preferred, at this 
season, or, if in summer, in the shallow junks which trade up to Mao Erh Shan, more than 200 miles in a direct line from An Tung Hsien. If all was peaceful, we should find several small river-ports, where carts from the Chinese interior bring grain, and An Tung merchants purchase and store it. The same carts convey back with them loads of American kerosene, cotton goods, Indian yarn, Southern Chinese and European sundries. Over the ice bound river we should pass small parties of Koreans, openly smuggling vast quantities of Chinese Samshu, or coarse whisky. This spirit is the curse of North Korea. Up river is Tung $\mathrm{Ku}$, a once important military camp in the old pre-Manchu days, now a trading-post. Inland, where until recently a forest stood, we shall find thousands of very old and common graves, but up one valley are several more important ones, stone pyramids, more like mounds, as rotten leaves and vegetation cover them. On a small hill there stands one of massive proportions, clear against the evening sky from the river. It is perfectly rectangular, each face the same, and composed of seven layers of enormous stones, resting on a raised foundation. The first layer contains blocks, about 15 feet, more or less, long, 6 feet high, and the same in breadth. Seven or eight of these (I forget exactly; my note-books were burned by the Boxers) form the base; a less number, or rather blocks slightly smaller, the second stage, and so on to the top; the apex has disappeared. The base measurement is over 100 feet, the height about 40 feet. Rather more than halfway up is an opening about 4 feet square, forming a passage which slopes down into a chamber, which is a cube about 20 feet each way. The walls are built of perfectly chiselled stones, each stone about 20 inches deep, bevelled towards the end on which the stone above rests and overlaps, in the old Phœnician style. The levelling is so perfect, that, although no mortar was used, a penknife could scarcely be thrust between the ancient joints. The ceiling has a cornice of one stone sideways the entire length, projecting about 15 inches, on which rests the one perfectly levelled, but not polished, stone, with no crack or fissure, that forms the ceiling, and on which tons of superincumbent blocks rest. In the centre of the floor towards the east side was a raised dais of polished black marble, with two sunken areas in which, the natives said, two stone coffins once rested. At the time, I could not understand why these coffin places should be so short; but in another place in Northern Manchuria, I was shown a stone coffin about the size required, which had just been dug up, and contained some badly cremated remains. Thus, this pyramid, with the others, no doubt contained two large stone urns. On the side of the one referred to could be traced the ancient Korean form of the Chinese character, Chi, for good luck. The opening faced west, and a curious Druidical-like shrine, composed of one large flat rock, on which are three upright rocks, forming three sides of a square, opening also west, with a huge stone 
cover as roof, was near the pyramid. All Chinese and Korean graves and shrines face towards the south. The outside stones are basaltic, and probably were brought down the river. The burial-chamber stones were all of fine grey granite, of which no traces could be found in the adjoining valleys, and $I$ was told none are known anywhere near. There are many other curious stone coffins, or coffins made of several stones, or even of a most curiously shaped brick found in different parts of Manchuria. These pyramids, buried for ages in an unknown forest, are interesting, and may in time give some clue to the people amongst the Northern Koreans, who sometimes show Caucasian and not Mongolian features.

There is a huge stone column near the above pyramid, with ancient Chinese characters, but I have never succeeded in obtaining a rubining, although I have tried. I imagine it to be of an intermediate date, however, and that the pyramid belongs to a far-away age, to the early empire which flourished in Manchuria and Korea, and whence Japan obtained its earlier civilization.

Our knowledge of Manchurian history is vague at the best, and such as we have is from Chinese sources, dealing almost entirely with wars and heroes. We are quite aware that this land has always played a most important part in the destinies of the Far East. There is, however, nothing at all reliable earlier than the Christian era, when a race, of whom the modern Koreans may be descendants, had a well-organized kingdom, east of Shan Hai Kuan, or the Great Wall, the breaking up of which allowed the northern Tartar tribes to harass China. There are indications of a pre-historic empire, and, little by little, evidence is being gathered of a race supposed by some to be akin to the Indians of Mexico, if not of Peru. Recently the Russian Coal Mining Company, which has what was deemed a most valuable concession near Fu Shun, about 20 miles east of Mukden, was much troubled by coming upon unknown workings at a great depth with the coal completely excavated, and showing an engineering skill of high order. There is nothing in China, ancient or modern, to indicate that its people ever had such mining abilities.

From Tung $\mathrm{Ku}$ up-river one;passes the massive block of mountains, all covered with dense pine forests, called Mao Erh Shan, bejond which is the Shin Kai Ho valley, now organized into a District Magistracy, magnificently fertile and rich in minerals, still largely forested, and where the junk traffic ends. On the Korean side opposite the Shin Kai Ho river-port, the forests cummence which were granted to the Russian Lumber Company by the Korean Government. Crossing the forest zone, where we note signs of copper and other materials, we enter the great high plain of Hai Lung-ch'êng, very fertile, and swarming with brigands, who will not, probably, molest us if we are unarmed. A few days will bring us to Kirin city, through a country capable, as 
nearly all Manchuria is, of being highly developed. Through Kirin city, over the frozen Sungari, we go on through 200 and more miles of rich agricultural land, with its last year's superabundant harvest awaiting in village granaries for the hosts of Russian soldiers to buy. Let us cross the Sungari at Harbin, and go north-east into the Amur province; there we shall find thousands of tons of grain which the farmers have feared to send down to the south this winter. Harbin promised, its builders hoped, soon to eclipse Moscow as a business and manufacturing centre. No spot in all Manchuria could have been more wisely chosen for the purpose. In the very heart of the richest corn land, of almost unlimited extent, with many great trade routes

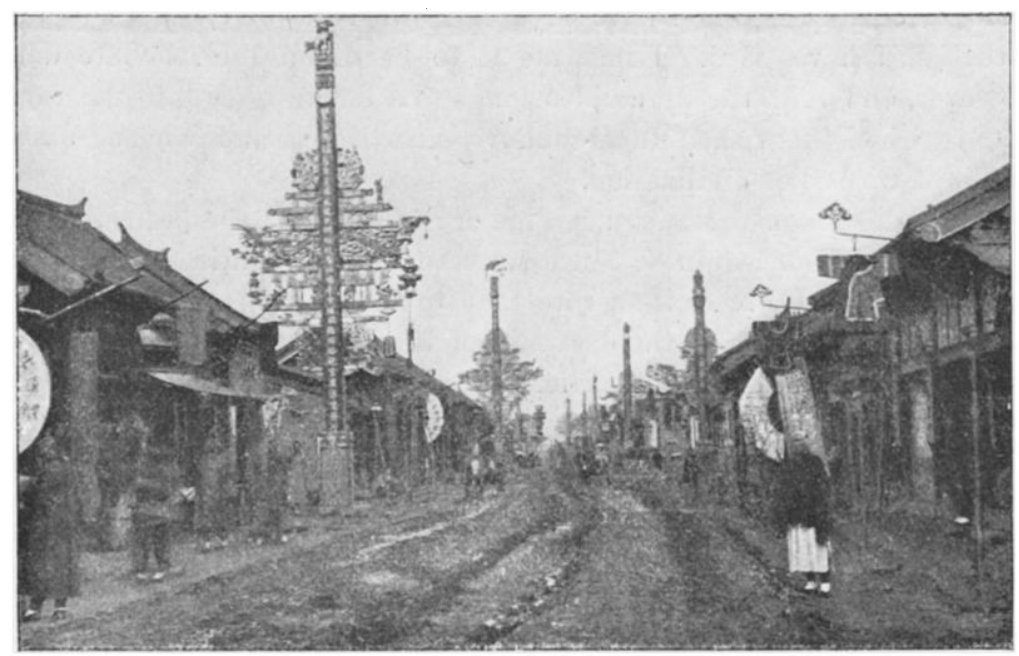

THE "SE PING KaI," OR street of Peace, MUkden.

passing near, and which would readily converge here, with its railways and noble river; the native population industrious, quiet, and keen on money-making; no wonder Harbin has grown rapidly. The Russo-Chinese Bank has ably helped the trade by its easy and longsighted policy with native merchants.

From Harbin we could travel, on the finest trains yet constructed, south-west through some of the best agricultural land in the world, down to Kung Chu Ling, where are large engine-works. There we should see a number of worn-out and useless American and French locomotives, which have been replaced by the splendidly built and powerful Russian engines. The lines through Manchuria are now well made, and, except in the rainy summer season, have nothing to fear. During winter, with bridges and culverts well guarded, the solidly frozen track cannot easily be blown up, although, no doubt, the robber 
bands may attempt it, as they hate the Russians, who have earned their ill-will, because they have striven to protect the poor law-abiding natives from these cruel outlaws.

Of politics I cannot speak, but permit me, in closing; to remark that $I$ am in a better position tban most Englishmen from which to judge the Russians in Manchuria, seeing that I have lived amongst them, and travelled widely, since their first arrival in the country, and I must say that, on the whole, they have behaved right well to the natives, and been very kind to Britishers in the interior.

The trade of Manchuria is developed but little; under a good Government it ought to be enormous.

According to Mr. Consul Hosie's careful and reliable estimates for 1899, amongst the chief items are beans, bean-oil, and cake, exported from Newchwang.in foreign bottoms, alone amounting to $£ 2,511,559$, to which at least a third might be added for junk trade from Newchwang, the Yalu, and other parts. Silk, of which much more could be produced, $£ 389,378$, exported by foreign vcssels, and much also by junks. Gold, native, intermit!ently worked, £204,266. Sundries, £144,408. Furs, $£ 23,070$. This is a mere bagatelle compared with what might be done. In 1899 the total exports, in foreign ships, amounted to $£ 3,783,914$; total imports, $£ 5,633,435$.

\section{ABOUT KOREA.}

By the Rev. C. T. COLLYER.

Was there ever a country bearing so many names as the peninsula we to-day call Korea? Let us go back as far as the rear 2350 B.c., and we find the Chinese historians, even at that early date, referring to the peninsula as the Kingdom of Cho-son, "The Land of Morning Freshness." Then we have the records of the native historians themselves, telling us, in the second century before Christ, of the Three Hans ; after which the country resolves itself into innumerable small fiefs through the next ten decades, until at the end of this period the various chieftains merge their interest in the contemporary kingdom of Sil-la (57 B.C. to 918 A.D.), Paik-Jay (17 A.D. to 660 A.D.), and Ko-Ku-ryo (36 A.D. to 672 A.D.). It was upon Sil-la, however, that the Fates smiled, for she not only outlived her neighbours, but absorbed them. The year 918 A.D. gave rise to the Ko-ryo dynasty, which, in its turn, was superseded by Tai-cho, the first king of the present dynasty, who, following the advice of the then Emperor of China, called his kingdom Cho-sen.

In 1897, soon after the close of the Chino-Japanese war, the present king (who, it may be mentioned, has no name), feeling it was undignified for him to remain a king while his neighbours of Japan, China, and 
KOREA

SOUTHERN M

TURLEY \&

THE GEOGRAPHICAL

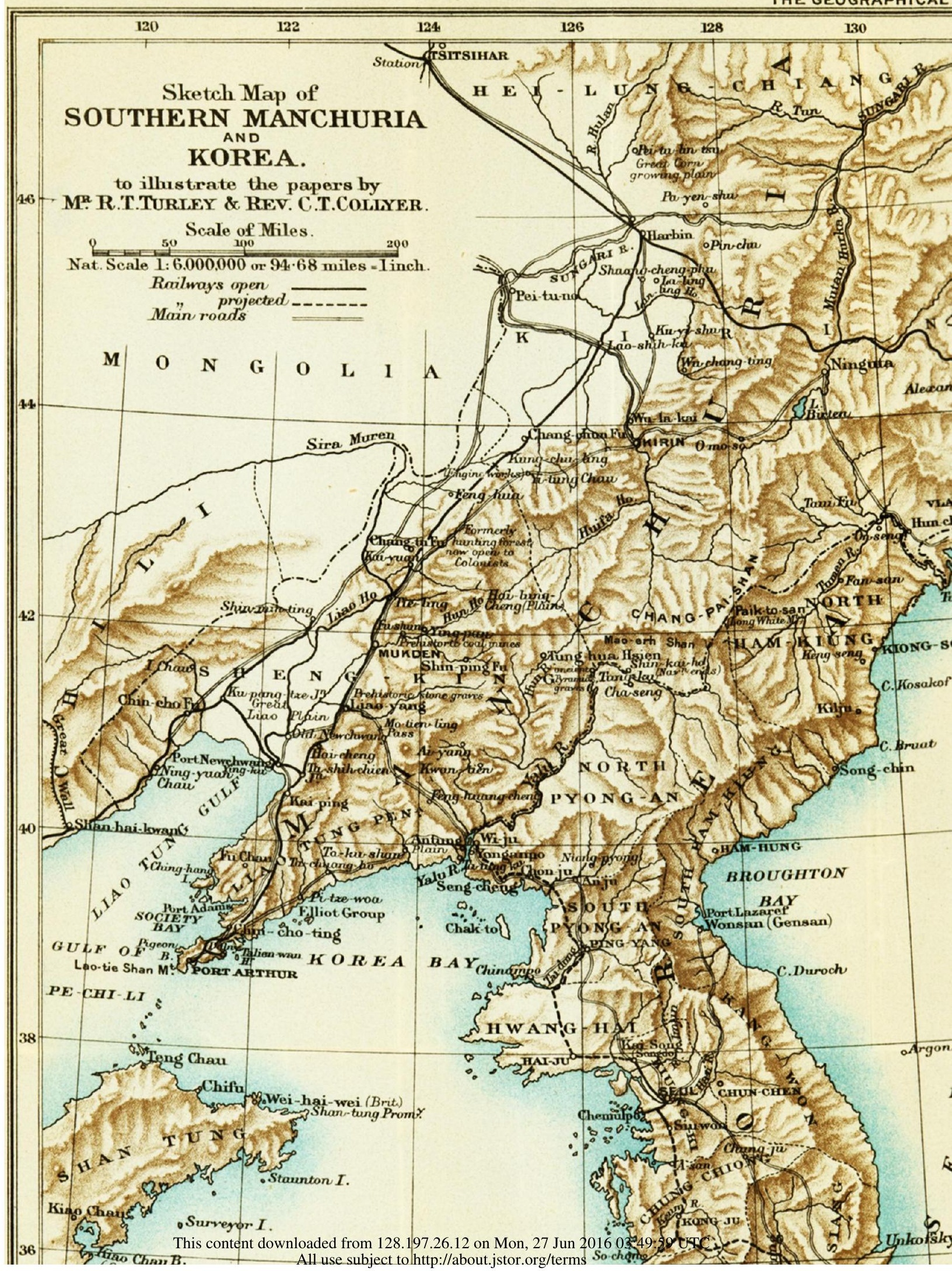


KOREA AND

SOUTHERN MANCHURIA

TURLEY \& COLLYER.

THE GEOGRAPHICAL JOURNAL, 1904

120

122

126

130

132

Sketch Map of

'HERN MANCHURIA AND

KOREA.

illustrate the papers by

TURLEY \& REV. C.T.COLIYER.

Scale of Miles

1:6.000,000 or 94.68 miles = Iinch.
Railways open
Main roads
o $\quad$ N G

\begin{tabular}{lll|llll}
$\mathbf{O}$ & $\mathbf{N}$ & $\mathbf{G}$ & $\mathbf{O}$ & $\mathrm{L}$ & $\mathbf{1}$ & $\mathrm{A}$
\end{tabular}

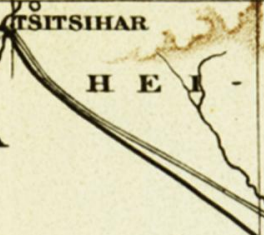

128

i

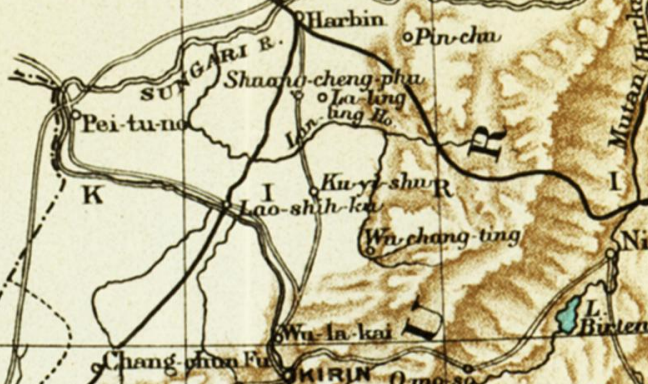

L U la I $_{\text {I }}$ A

(5)

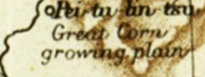

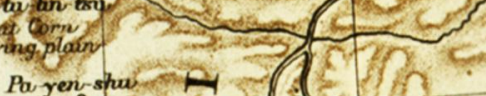

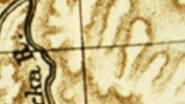

46
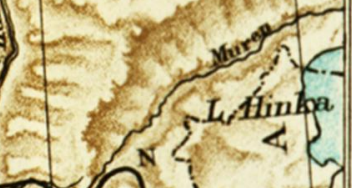

4 
